\section{SOME OBSERVATIONS ON LONG-EARED AND PALE HEDGEHOGS IN GUJARAT}

\author{
Raju Vyas \\ Sayaji Baug Zoo, Vadodara, Gujarat 390018, India.
}

Table 1. Long-eared Hedgehog (Hemiechinus collaris) recorded in different locations in Gujarat State.

\begin{tabular}{ll}
\hline Location & $\begin{array}{l}\text { Date of } \\
\text { record }\end{array}$ \\
\hline Alembic Colony, Vadodara City, Vadodara District. & $12 . i v .1989$ \\
Out scert of Surendranagar, Surendranagar District & xii.1990 \\
Godhara, Panchmahal District & $3 . i i i .1998$ \\
Khijadia, Rampara Wildlife Sanctuary, Rajkot District & $16 . i x .1998$ \\
Hingolgadh Nature Education sanctuary, Rajkot District & $25 . x .1998$ \\
Near Sanand, Ahmedabad District & $4 . i i i .2000$ \\
Near Tuga Village, Kachhch Desert Sanctuary, Kachhch District & 6.iii.2000 \\
Panandhro, Narayan Sarovar Sanctuary, Kachhch District & 22.viii.2000 \\
Porbander City, Porbander District & $13 . x .2000$ \\
\hline
\end{tabular}

On the night of 13 October 2000, around 22: $30 \mathrm{hr}$, I observed a Long-eared Hedgehog (Hemiechinus collaris) feeding on insects under a lamp post near the lighthouse at Porbander City. I observed the animal for about 30 minutes and noticed that the shy animal ran behind the bushes at any slight disturbace or the appearance of a vehicle. I collected the Hedgehog for a closer examination. The specimen was a male and had dark black coloured spines on the back and the under body part had smooth black coloured fur. Its long left ear was heavily infected by ticks. The animal weighed $450 \mathrm{~g}$.

Little information is available on the distribution of the species in literature, except that the species is distributed in dry plains and deserts of Pakistan and India (Kachchh, Rajasthan, Punjab and the former N.W.F.P. and the neighboring areas) (Prater, 1995). In addition, Acharya (1949) mentioned that the species is disturbuted in northern and southern Gujarat but he has not mentioned any specific locality about the species, except records from Palanpur and Dissa. Based on a photograph of the species, Singh (1998) made a statement that the species is found in Little Rann of Kachchh, also.

I have recorded the species in different parts of Gujarat State, during the last ten years (Table 1). The species is distributed widely in Gujarat State along with another smaller species of Pale Hedgehog (Hemiechinus micropus) but is not as common. Both species share same distribution range in Gujarat and the same habitat.

I observed an interesting feeding behavior of a Pale Hedgehog during my recent visit to Narayan Sarovar Wildlife Sanctuary, Kachchh District. A Pale Hedgehog was found dead on the road near Panandhro Village run over by a vehicle. On the second night I saw a live pale hedgehog on the same road (near Varma nagar) feeding on a dead Monitor Lizard (Varanus bengalensis), another victim of vehicular traffic. This indicated that the previously found dead Pale Hedgehog could have been a victim of a speeding vehicle while feeding on a roadkill. The same night, I saw Long-eared Hedgehog at the same spot I had found the dead Pale Hedgehog.

As a zoo-man, I have some experience of these two species in captivity. Pale Hedgehog is easier to keep since it accepts food, especially vegetable items and survives long time in captive condition. On the other hand Long-eared hedgehog does not accept food and does not survive for long in captivity.

According to CAMP (Conservation Assessment and Management Plan) workshop 1997 (Molur et al., 1998) both the species are evaluated as Lower Risk least concern. However, these smaller and lesser-know mammalian species need special attention. It is my experience with the species that in the earlier days they were found commonly at night when driving down rural roads and often killed by speeding vehicles. Now-a-days they are a rare sight. It is possible that the population of both hedgehog species may have reduced due to habitat destruction, alteration in the habitat, vehicular traffic (roads) and large amount of use of insecticides in agricultural fields.

\section{References}

Acharya, H. (1949). Gujaratni Pranioni Sarvanukramani. Gujarat Prakruti Mandal, Ahmedabad, Gujarat.

Molur, S., P.O. Nameer and S. Walker (Editors) (1998). Report of the Workshop 'Conservation Assessment and Management Plan for mammals of India' (BCPP-Endangered Species Project), Zoo Outreach Organisation, Conservation Breeding Specialist Group, India, Coimbatore, India, 176pp.

Prater, S.H. (1995). The Book of Indian Animals. Bombay Natural Hisotyr Society Bombay, 324pp.

Singh, H.S. (1998). Wildlife of Gujarat. Gujarat Ecological Education Research Foundation, Gandhinagar, Gujarat, 123pp. 